\title{
The "Illusion" of Social Research/ Action. Reflections on Neo-Colonial Pedagogy
}

\author{
Maciej Jabłoński \\ Kazimierz Wielki University, Poland
}

DOI: http://dx.doi.org/10.18778/1733-8077.17.1.7

\section{Keywords:}

Disability;

Postcolonial

Pedagogy; Neo-

Colonial Pedagogy;

Disability Studies

\begin{abstract}
In the text, the author demonstrated that regardless of the prevailing regime, the State, by relying on separate laws for people with disabilities (or any other minority group), has created and continues to create colonies of sorts. In the first part of the article, the author presented the difference between postcolonialism and neo-colonialism in relation to people with disabilities and in Disability Studies. Afterward, he highlighted the illusory nature of research and, above all, educational activities in favor of people with disabilities. He argues that in the case of this group of people, we are dealing with neo-colonial pedagogy rather than a postcolonial one.
\end{abstract}

Maciej Jabłoński is an Assistant Professor at the Faculty of Pedagogy of the Kazimierz Wielki University in Bydgoszcz. His main scientific and research interests focus on the phenomenon of disability, in particular intellectual disability, and the issues of quality of life, social and civic education of people with disabilities. He adopts a qualitative methodological orientation, in particular from the perspective of action research, aiming to reveal the subjective view of the world of people with intellectual disabilities.

email address: macias@ukw.edu.pl
Society recognizes only slaves and rulers-rulers who impose their content and forms, and slaves, whom these forms are imposed upon. It does not recognize independent human beings who have no strength to be rulers and will not accept being a slave. [Elzenberg 1994:413 (trans. MJ)]

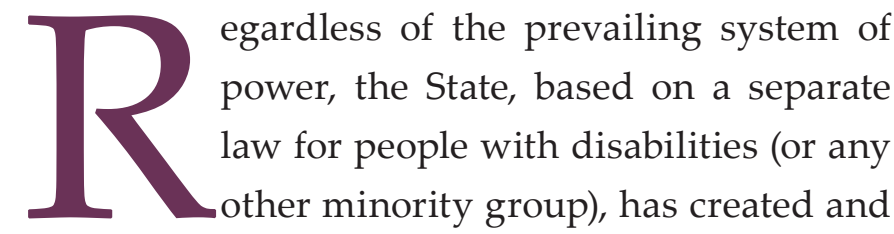


continues to create colonies of sorts. ${ }^{1}$ Our experience, feelings, knowledge, and perception show us that legal regulations and top-down paradigmatization of areas of knowledge are mostly meaningless, resulting only in the fact that people with disabilities become slaves to the system of areas and fields colonized by able-bodied and strong groups, who toss them "pieces and scraps of freedoms" from time to time, which are not necessarily adapted to their needs (see: Rzeźnicka-Krupa 2009; Zakrzewska-Manterys 2010; Jabłoński 2016; 2018). People with disabilities, as well as other minority groups, face the fact that educational researchers were late to recognize the importance of culture

\footnotetext{
${ }^{1}$ Some authors, including Zenon Gajdzica, use the term "reserve." It assumes that the reserves generate and identify problems, or are the results thereof. Parallel to the context of this approach are the concepts of understanding disability. People with disabilities can, like the able-bodied, take the areas with the approval of society, often as a result of their own activity and smart action, or be "exiled" to such areas (Gajdzica 2013:1617). Zenon Gajdzica follows a concept developed by Goffman (2011), assuming that: 1) GOOD is the absence of territorial restrictions for people with disabilities manifested in their full participation in culture and other commonly available benefits, in the absence of restrictions in fulfilling valuable social roles, in full access to education, and in social respect; 2) DEMANDS constitute laws, customs, and norms, both formal and informal, defined by the able-bodied majority, a system of social empowerment and access to valuable roles, as well as control and use of other goods controlled by them; 3) CLIENT is a person with disabilities, who can also act as their own AGENT; 4) OBSTACLES are common barriers (architectural, social, cultural, educational, legal); 5) AUTHOR (counter-client) is the able-bodied society, particularly its part which does not recognize the needs and potential of people with disabilities; 6) AGENTS are specialists, social workers, professionals, representatives of people with disabilities, who are usually able-bodied representatives of society representing its interests (Gajdzica 2013:15). Personally, I believe that a closer and more accurate term to describe a given place and a certain way of "socio-cultural interaction" is the term colony, which is referred to as a land or area under the control of a given state, usually an overseas territory, dependent on that state, serving as an area of its political expansion and economic exploitation. A place of forced residence, isolated from society, for example, a colony of people suffering from leprosy. Colonialism-“the policy or practice of acquiring full or partial political control over another country, occupying it with settlers, and exploiting it economically" (Oxford Dictionary [https://www.lexico.com/ en/definition/colonialism; retrieved January 02, 2021]).
}

and cultural differences as key components of successful research practice and beliefs. ${ }^{2}$ Peculiar attempts to allow a person with a disability to speak, which so far existed as subordinate through the implementation of, for example, concepts such as self-advocacy and independent living focus on a person with a disability in the background, their subjective choices, and independent life to the extent possible. Being your own advocate in charge of your own affairs and independent life are the slogans of the creators of these concepts. Therefore, the key research issues of power relations, initiation, benefits, representation, legitimacy, and responsibility continue to be addressed within the framework of goals, concerns, and interests of the researcher's culture (cf. Bishop 2009:167-207 [about Kaupapa Māori]). The ongoing neo-colonial dominance of the majority's interests of the able-bodied in research and social activities aimed towards people with disabilities continues. Despite appearances, the spaces of people with disabilities are not postcolonial in nature, but rather neo-colonial, as the contemporary strategies of enslavement/colonization have become more sophisticated, which I will try to present in the following paper. We must remember that the term "postcolonial" does not refer to people who are at the very bottom of this hierarchy, who still operate on the distant, economic outskirts of the nation-state-in other words, there is nothing "post" about their colonization (Loomba 2011:25). The precarious situation often stems from the conviction that the dependence on the able-bodied is the only "right" way to live (see: Wlazło 2014). This illusion of sorts has a significant impact on the attempts to demystify the selected social activities presented in the paper below.

\footnotetext{
${ }^{2}$ Concerning the culture of people with disabilities, a debate is ongoing as to whether it is appropriate to talk about the culture or the group (see: Barnes and Mercer 2008:120-124).
} 
The main goal of the text is to show the difference between postcolonialism and neo-colonialism in the context of social research on people with disabilities. Asking the question of whether we are dealing with specific postcolonialism in relation to this social group, which implies decolonialism, that is, as we read in the Oxford English Dictionary-withdrawal of colonial powers from their former colonies; gaining political or economic independence by the colonies (as cited in Kennedy 2014:12). It should be remembered that the keywords in this definition are "withdraw" and "gain," terms that evoke the association with a peaceful financial transaction carried out with mutual consent; the associations are strengthened by the synonym of decolonization suggested by the dictionary-transfer (handing over), the word referring to legal language, meaning the transfer of property from one person to another (Kennedy 2014:12). Are we dealing with neo-colonialism by exposing/pointing to the illusory nature of research and, above all, mock activities in areas such as economy, social policy, and education?

\section{On Colonial Discourse}

According to Peter Pels, three different ways of defining colonialism can be found in anthropology. It is interpreted as: 1 . the next stage of development, the ongoing modernization process; 2 . a political strategy or experience of exploitation and domination; 3. an open field of battle and negotiation (Pels 1997:164).

The various and disproportionate ways of understanding colonialism indicate that its meaning is not predetermined, nor is it a foregone conclusion. Referring to the definitions presented by Pels, the first of them can be considered as an exemplification of the interpretation made from the point of view of the Enlightenment modernization discourse; the second is an expression of its criticism, embedded in Marxist theory; the third, in turn, brings to mind postcolonial reflection stimulated by post-politicalism (see: Songin-Mokrzan 2014:83).

Ben-Ari distinguishes at least three types of reflection focused on tracing the connections between the science of the Other and colonialism. The first is to consider anthropology in terms of a practical discipline focused on the production of knowledge that can be applied in a specific social environment. The second is focused on the search for connections between theory (mainly the evolutionist and functionalist models) and colonialism. The third deals with the role that our discipline has played in the production and in sustaining the "colonial discourse" (Ben-Ari 1999:383). It must be remembered, though, that colonial discourse itself is not a new, fashionable synonym for colonialism-it signals a new way of conceptualizing the interaction of cultural, intellectual, economic, and political processes in the formation, perpetuation, and dismantling of colonialism (Loomba 2011:70).

\section{"De-Colonization of the Minds"}

Bill Ashcroft's introduction to The Empire Writes Back (1989:1) - a seminal work in postcolonial studies-reminds us that "more than three-quarters of the people living in the world today have had their lives shaped by the experience of colonialism." The (post-)colonial condition, apart from species, race, class, caste, and gender identification, may be treated as one of the basic determinants of contemporary understanding of individual and group human subjectivity, with the ultimate goal of postcolonial research being-as the Kenyan writer, Ngũgĩwa Thiong'o (1986), puts it-decolonizing the minds. 
This decolonization is linked to the criticism of Eurocentrism, common in the whole of postcolonial studies, albeit carried out in different manners and understood in a variety of ways, as well as to the (unrealistic) project of "provincialization of Europe" by means of promoting postcolonial kinds of knowledge (knowledge of resistance) using postcolonial literature, history, art, and science, contesting the Eurocentric way of knowing with its essentialism, metanarratives, universalism, the idea of progress and purpose, as well as thinking in binary opposites as an ideology legitimizing imperial dominance (Seth, Gandhi, and Dutton 1998:8-9).

When faced with quite strong criticism, the colonial authorities and their successors were interested in propagating a selective and censored version of events, showing decolonization as a rational process carried out at the will of the political elites, whose decisions confirmed the legitimacy of the governments they represented and the logic of the international system against which they demanded loyalty (see: Kennedy 2014).

\section{Contextuality of Postcolonialism}

Mina Davis Caulfield, in an article published in Reinventing Anthropology, suggests that the concept of subordinate exploitation should be presented in a much broader context, not only in relation to economic, but also social and cultural aspects of the relationship between the West and the non-West. The author thus draws attention to the fact that as a result of the influx of new market and cultural patterns, not only traditional social structures are changing, but also local norms and values, strategies of action, and ways of defining the cultural and ethnic identity of the subjects (see: Caulfield 1972:197).
The critical analysis of the effects of colonialism on both the colonizers and the colonized, carried out while constantly keeping in mind the superiority of Europe over cultures and territories colonized by its empires, needs to take a look at the issues of presenting and perpetuating stereotypical ideas of the "other" and the role these representations played in the formation of the postcolonial subject. As Samuel P. Huntington (2007:66) pointed out, people from outside the Western civilization remember very well that the West won the world not by the superiority of its ideas or values or religion, but rather by its superiority in applying organized violence.

These days, however, postcolonialism is also understood as an intellectual approach characterized by constant criticism of institutions that have the tools to exert coercion/pressure on people. This approach to postcolonialism was postulated by Michel Foucault (1987; 2006), as well as Noam Chomsky (2008; 2018), among many others. Postcolonialists (see: Gandhi 2008; Young 2012) stress that there is no room for thinking in terms of progress and the conviction that there are "better times" coming after years of oppression. We also need to keep in mind that postcolonial theory pays particular attention to the consequences of colonialism. The apparent persistence of the colonial system and the stigma of colonial past, which resonates in contemporary culture on the macro-scale in independent states and on the micro-scale in various minority groups, still is one of the key issues for their identity, as well as manifests itself in the form of new, neo-colonial forms of subordination, causing tension not only between the colonizer and the colonized, but also illuminating that: "there is a certain tension between those who consider postcolonialism to be a geo-historical phenomenon and those who see 
it as a theory offering ideologically charged research directives stemming primarily from various forms of Marxism, post-structuralism, and deconstruction" (Domańska 2008:6 [trans. MJ]).

The postcolonial perspective becomes possible to apply in the analysis and description of the phenomena involved in the relations of power/domination and subordination, the superiority of the colonizer over the cultures and territories colonized by the empire. The common ground for many of the possible approaches and definitions of postcolonialism is its nature as a critical discourse in which an effort is made to read and understand individual and collective subjectivities intertwined with the experience of colonization, decolonization, exclusion, or hybridization, entangled in the relations of subordination and domination, located in the social space in marginal or central positions (see: Krzemińska 2019:325).

Postcolonialism should assume a specific deconstruction of the existing world by, for example, introducing alternative knowledge into power structures. As Robert Young (2012:19-20) observes, it aims to change people's thinking and behavior and to create fairer relationships between the peoples of the world. Postcolonialism disturbs the world order. It threatens privileges and power. Its radical program assumes the demand for equality and prosperity for all beings on earth.

However, there is a risk, and it is quite great, that the process of decolonization does not necessarily involve the rejection or denial of imperialism. Neither has it led to the complete exit of empires from the political scene. Most often, they have just reborn in a new shape (see: Kennedy 2014). And in this situation, we should speak of neo-colonialism.

\section{Neo-Colonialism}

As we read in Kennedy's Decolonization (2014:110), the most striking example of neo-colonialism is perhaps France's relationship with its former holdings in Western and Central Africa. This territory was called Françafrique and its relations with the metropolis were characterized by the slogan partir pour mieux rester (leave to stay). Their natural resources were still exploited under secret contracts with French companies, and French specialists had a disproportionate influence on the business and bureaucratic system of these countries. France retained control of military bases in the region and used the troops stationed there to intervene in the internal affairs of Western and Central African states. Since 1960, the French have carried out over twenty military actions in this territory, thanks to which governments cooperating with Paris retained power and less submissive ones were overthrown (Kennedy 2014:110). So we are dealing with the illusion of decolonization, where actually neo-colonialism as an idea came out earlier than postcolonialism and is connected with the direct consequences of the decolonization process. While postcolonialism may be understood as an epistemological guideline allowing researchers to better understand the social, political, and economic situation of countries, which emerged as a result of decolonization, neo-colonialism may be defined as both the political strategy of former empires towards their former territories, as well as the state of countries, which emerged as a result of decolonization (Crozier 1964:11).

One of the most important voices that showcased the essence of neo-colonialism was the President of Ghana, Kwame Nkrumah, one of the main ideologues of so-called African socialism, who held office from July 01, 1960 to February 24, 1966. Speaking 
of neo-colonialism, he claimed that, "The essence of neo-colonialism is that the State which is subject to it is, in theory, independent and has all the outward trappings of international sovereignty. In reality, its economic system and thus its political policy is directed from outside" (as cited in Malendowski 2000:321 [trans. MJ]). It is thus apparent that any attempt at showing the difference between post and neo-colonialism is quite a difficult task, which will probably result in the reader getting lost in the terminology. I believe that for the sake of the discourse presented in this paper, we also need to cover the difference between imperialism and colonialism. The differences between these two approaches and systems are defined in a variety of ways, depending on their historical varieties. One useful way of distinguishing these systems' concerns refers to the spatial, instead of temporal, criteria.

[We can thus] think of imperialism or neo-imperialism as the phenomenon that originates in the metropolis, the process which leads to domination and control. Its result, or what happens in the colonies as a consequence of imperial domination, is colonialism or neo-colonialism. Thus the imperial country is the "metropole" from which power flows, and the colony or neo-colony is the place which it penetrates and controls. Imperialism can function without formal colonies (as in United States imperialism today [as well as Russian imperialism and imperialism exhibited by some European countries]), but colonialism cannot. [Loomba 2005:12 (sentence in bold added)]

These different understandings of colonialism and imperialism complicate the meanings of the term "postcolonial," a term that is the subject of an ongoing debate. It might seem that because the age of colonialism is over, and because the descendants of once-colonized peoples live everywhere, the whole world is postcolonial...To be- gin with, the prefix "post" complicates matters because it implies an "aftermath" in two senses-temporal, as in coming after, and ideological, as in supplanting. It is the second implication which critics of the term have found contestable: if the inequities of colonial rule have not been erased, it is perhaps premature to proclaim the demise of colonialism. A country may be both postcolonial (in the sense of being formally independent) and neo-colonial (in the sense of remaining economically and/or culturally dependent) at the same time. [Loomba 2005:12 (emphasis added)]

Thanks to this the next question arises: Is the State really/realistically about helping people with disabilities? Or does help happen while realizing your own political ambitions and fighting for your own life stability? By using the violence, which I understand after Slavoj Žižek as a kind of objective violence called systemic violence, that is, a feature of all systems whose task is to maintain a level of normality in society. We do not see it because it organizes the reality (it is contained in social, economic, and political systems) (see: Žižek 2010:5-6; Misiarz-Filipek 2015:10), which consists of making the appearance that something is necessary when in fact it is voluntary. Each entity subjected to objective violence says: I have no choice as to what his social role demands of him, he persists in "bad faith." We can easily imagine the circumstances in which this confession will be true to the extent that there is no choice in this particular role (Berger 1988:135-137).

These are modern neo-colonialists (e.g., technocrats, eurocrats, professionals, etc.) who in order to avoid the social-cultural collapse of colonialism rebuild it in a rational way, making their subjects dependent on their own charity, which is omnipresent in almost every area of social life. According to Piotr Nowak (2014:4-5 [trans. MJ]), 
It is difficult to defend oneself from the organized "charity" of neo-colonizers, disguising themselves as philanthropists. Neither officials nor politicians can protect us since they were the first to fall prey to them. Neither can we find help from our teachers or respected authorities-they also took from them. There is no good way out of this impasse-the impasse of philanthropy-which has affected the whole of Europe. However, one thing is certain-nothing is free. We paid for our wealth with our freedom, faith gave way to the need for miracles, the mystery was dispelled by the seemingly unlimited access to knowledge and information.

Although intellectuals declare their intention to allow the voices of once colonized peoples and their descendants to be heard, in fact, they close off both their voices, as well as a legitimate place from which those critics can speak (Jacoby 1995:30).

Summarizing this part, one may be tempted to say that the basic difference between postcolonialism and neo-colonialism is that neo-colonialism "tears off the mask" of decolonization, which, in fact, does not exist and cannot be said to have any (POST!) colonialism.

In such a situation, despite the visible changes in the socio-cultural space, people with disabilities seem to still be found. They occupy a social position the designation of which is being colonized by so-called able-bodied society, which, as a culture of "superiority"/dominant, because it grows on the foundation of "normality," exercises power over the "subordinate" intellectually disabled (Krzemińska 2019:322).

People with disabilities, assuming their location in the socio-cultural space, seem to succumb to the domination and power of the able-bodied part of society, including intentionally established institutions and en- tities operating within it, acting as professionals. This is because, by situating themselves in a privileged position, they fund/establish certain frameworks and boundaries in which a person with a disability can exist. At the same time, they launch a specific repertoire of actions and practices undertaken against it, which take the form of a decolonization process.

A person called intellectually disabled occupies an unusual place in society. It is commonly known that this is an unfavorable place, because a person classified in this way is not only not treated as a valuable person in society, but is most often even excluded from the mainstream of the modern world (Źółkowska 2013:40).

\section{Neo-Colonial Educational Practices-We Are as Disabled as We Agree to Be}

Undoubtedly, the end of the $20^{\text {th }}$ century and the beginning of the $21^{\text {st }}$ century brought a completely different approach to this issue, including the birth of interdisciplinary Disability Studies, breaking the one-sided approach to this phenomenon (Barnes, Oliver, and Barton 2002). Colin Barnes points out that the scientific sources of the ontology of disability studies arose on the wave of criticism of the social model of disability because "it is argued that the conceptual distinction between impairment and disability upon which the social model rests is false" (Barnes 2003; Podgórska-Jachnik 2016:13-36). In the area of special education in Poland, the dominant way of practicing this discipline still remains, rooted in the scientistic way of thinking, a structuring approach in the light of which disability is a phenomenon determined by specific features available to us in the objectifying act of cognition, implemented in the context of dividing reality into the sphere of what is normal and what is pathological (see: Canguilhem 2000; Kosek-Nita and Raś 2000). 
These processes in contemporary discourses gain a more general social and cultural perspective due to the fact that they are characterized as affecting not only disabled people, but also other minority social groups, which, due to specific social mechanisms, are discriminated against, marginalized, and excluded from the mainstream of social life, and the universal game for status and power. The changes and transformations that have taken place in contemporary humanities and in the understanding of certain fundamental notions that shape it (including the categories of identity and the issue of social practices that construct the subjectivity of individuals) have resulted in a reorientation of the area of research interests and ways of exploring the social world and the world of culture. Where the most important seems to be the search for social and cultural mechanisms of constructing these meanings, shaping practices applied to people recognized as disabled, and thus launching attempts to understand what the phenomenon of disability is and how it is perceived in different communities, groups, cultures, in other words-what meanings shape the individual and social identity based around damages and dysfunctions of "body and mind" and what social consequences may be (Rzeźnicka-Krupa 2009:12).

Contemporary trends in the approach to the issue of disability describe the assumptions of interdisciplinary studies on disability and the inclusive movement in contemporary society. A special distinguishing feature of the new approach is the recognition and development of the concept of subjectivity and autonomy of people with disabilities, but also the identification of new determinants of inequality and exclusion. The multiple of this exclusion, caused by the coexistence of several factors, is the basis for the theory of the interaction of oppressive factors in social systems built on domination and submission. Dorota Krzemińska (2012:55) writes about forcing people with disabilities into the strategies of "dependent and unhelpful cripples" when stating that a colonized intellectually disabled is most often seen as an incapable, dependent, requiring constant control-as such, a wide practical and operational sphere needs to be launched for them, which in its repertoire of various offers designed for an intellectually disabled adult will create conditions for their continuous improvement-to improve becoming a constant task imposed throughout life. And it is none other than a paternalistic parent, an overprotective professional-they prepare a whole range of assistance offers, making them addicted to themselves, or otherwise colonizing a disabled person.

The mentee is doomed to a repertoire of undertakings and activities planned by an able-bodied therapist "who in his zealous pursuit of the rehabilitation mission designs activities that do not necessarily correspond to the actual needs of the disabled person" (Krzemińska 2012:56 [trans. MJ]). Are we dealing with a case where concepts such as "ethnic" (disability, etc.) postcolonial have become a metonym for something fashionable and marginalized at the same time? Do we not notice this regularity consisting in the fact that the name of the study on disability may become a carrier and attractive model for conducting social and cultural research in Poland for special educators and sociologists? Unfortunately, it exists only in the declarative layer of scientists, in view of a completely different reality and research paradigms in which given academics exist.

For if academics declaring that they conduct studies on disability ignore social and cultural constructs and models of disability, and in fact conduct research in a clinical model focused on therapy and repair, one can be sure that they do not pursue studies on disability, despite previous declarations (Borowska-Beszta 2016:38). 


\section{Neo-Colonial System Violence}

The essence of neo-colonialism in education is based on excluding a part of the group, for example, due to health or disability, from the rights available to the general public, while building the conviction among teachers, educators, and parents that it has to be done and that it is what is best for them. While a developmental matrix is still applied to the lives of people with disabilities, as proposed by great theorists of developmental psychology, I consider such a way of using the developmental approach to research into adulthood of people with disabilities to be a waste of an opportunity to create a new paradigm in the study of issues concerning disability, as well as a theoretical approach, which may not contribute to progress in providing effective assistance in the development of people (Kowalik 2012:39). In addition, pathology serves as a way to adjust, as a reaction to factors harmful to the system and a way of dealing with them in such a way as to keep the system alive (Kościelska 1995:197). Unfortunately, as it turns out, it does not bother anyone that the right of their children and students has been restricted, and what is most puzzling is that it has been restricted-in my opinion-in breach of the applicable law in Poland. As Bogusław Śliwerski (2011:10) pointed out, “We are dealing with a situation where self-government stands against self-government, or pseudo-self-government, or self-government only appearing to be self-government, in a way that divided self-government into individual entities," or into groups of able-bodied students, students with mild intellectual disabilities, excluding, among others, students with moderate and severe intellectual disabilities from the process of creating student government in schools. To quote Article 85, item 8 of the Education Law of 2016, which states that, "The Minister in charge of education shall specify, by means of a regulation, the types of schools and institutions in which no student government is established due to the necessity of using a special organization of educational activities and working methods in the school or institution, as well as due to reasons concerning the upbringing, care, and resocialization." ${ }^{3}$ Such a list of types of schools and institutions was laid out in the regulation of February 23, 2007 by the then Minister of National Education, Roman Giertych. The list includes special schools for children and young people with moderate and severe mental disabilities, special education centers for children and young people with moderate and severe mental disabilities, centers for children and young people with profound mental disabilities, as well as children and young people with multiple intellectual disabilities, enabling them to fulfill their obligation to receive one year of preschool education, compulsory schooling and compulsory education, correctional facilities and youth shelters, and schools in penal institutions.

What is interesting is that when I asked the Ministry of National Education about what kind of research, consultations, and other sources allowed the decision whether these schools and these groups of students are not able to create a student government, to date, I have only received information confirming the functioning and treatment of people with disabilities by the authorities (in this case, the Ministry of National Education) according to the medical paradigm and objectifying them. In response to my question, I received what follows:

In my professional opinion, any initiative to reinforce the methodological and scientific basis for the identification and correct application of subjective regulations

\footnotetext{
3 See: https://isap.sejm.gov.pl/isap.nsf/DocDetails.xsp?id=WDU20170000059 [trans. MJ]. Retrieved January 02, 2021.
} 
(regarding student governments in this case) is positive, which is why I encourage you to continue your work. In particular and in the context of the quoted articles of the Constitution, it is worth noting that the principle of equality is not absolute. In this context, we may consider the reasons and premises which could have been the basis for the legislation obliging the Minister to exclude some institutions from the regulation (perhaps there are no students in some of them, perhaps in some cases it is due to medical considerations, etc.). [official e-mail correspondence with the Ministry of National Education, 2015-03-05 (trans. MJ, emphasis added)]

It is this above statement that is very important and shows the specific colonial aspirations of power, which is entangled in dependence on tendencies and influences: the past-"traditionalism" and the present-"postmodernity," "medicalization" and "humanization," objectification and recovery of subjectivity. As we can see, the past of thinking in the context of people with disabilities still has a normative dimension confirmed by people of science. As we see, some researchers of student government hold a similar belief. Mariusz Grążawski (2011:32 [trans. MJ]) states that the "list of exemptions is therefore significant, but seems justified."

In the above situation, I contacted the Ministry of National Education and Mariusz Grążawski and asked them to present research, public consultations, et cetera, which would in any way confirm their belief in the justified nature of excluding a particular group of students from the possibility of creating student governments. To this day, I have received no response from Grążawski. The Ministry of National Education, after my repeated reminders, replied that

The Ministry of National Education conducted a new query in the archives of the Ministry of National Ed- ucation and at the level of individual departments of the Ministry of National Education. On the basis of the information obtained, it appears that the documents describing the process of creating the final wording of the above-mentioned regulation have not been preserved. We should consider that the above situation was caused by the following circumstances: - the obligation to archive the final document, including the definitive text of the regulation with the signatures of the leading department and other cooperating departments (the document was provided) and, accordingly, the lack of justification for archiving preliminary versions, working documents, and drafts; - the obligation to include an impact assessment in the justification to the regulation, which must describe the results of public consultations;

- nearly a decade since the content of the regulation was drafted, along with the fundamental organizational and staffing changes that occurred during that period at the Ministry of National Education. [official letter no. DKO-WEK.431.22.2016.AK, 2016-1016 (trans. MJ)]

It is puzzling that no documents from public consultations concerning an issue as important as student government have been preserved in the archives of the Ministry of National Education. All while we know perfectly well that the idea of

civil society is implemented mainly in a process of creative cooperation and negotiation-in a process involving subjects free from cultural, religious, and philosophical prejudices. There are no managers or subordinates in self-government. There are only those who have committed themselves to do something for the common good and there are all those who control and evaluate it. Both parties need to benefit from it. Self-government that does not benefit everyone is no self-government. [Radziewicz 1985:12 (trans. MJ)] 
Another aspect, which I consider to be even more puzzling, is the fact that the said regulation of February 23, 2007, on the types of schools and establishments which do not have a student government, namely, item 2 of the said regulation-Public Consultation on Regulatory Impact Assessment, reads: "In the course of the public consultations, the Polish Teachers' Union (PTU) made a comment. The comment was taken into account" (Regulation of the Minister of National Education of February 23, 2007, Regulatory Impact Assessment [trans. MJ]).

Therefore, I contacted the PTU via e-mail, asking for an opportunity to access the documents concerning the public consultations carried out. It turned out, which was particularly surprising, that the PTU claims that in the given year, namely, 2007, it did not participate in any public consultations for the Ministry of National Education.

As one may see, in this particular case, we have normative acts, which result in far-reaching consequences for a large group of students. However, neither the Ministry of National Education nor the PTU is able to present documents from the public consultations. I have a feeling that someone has tried, and, unfortunately, is still trying to, as philosopher Harry Gordon Frankfurt would say, bullshit us. "The bullshitter may not deceive us, or even intend to do so, either about the facts or about what he takes the facts to be. What he does necessarily attempt to deceive us about is his enterprise. His only indispensably distinctive characteristic is that in a certain way he misrepresents what he is up to" (Frankfurt 2005).

The Ministry tried to prove that for the sake of the welfare of these students, they would not get to form their student government, while, in my opinion, depriving young people of the possibility to learn about governing themselves is a kind of an assault on their freedom. According to Aleksander Kamiński (1965:9 [trans. MJ]), self-government

is a variation of the principle postulating to lead the student to independent and conscious management of their own conduct and behavior, in other words, to self-discipline as a form higher than the principle of external punishment, leading to an upbringing in an attitude of obedience and submission. Upbringing focused on self-discipline postulates placing the student in an independent position, in situations requiring them to make choices.

\section{Instead of a Conclusion}

At this point, I believe, it is worth our while to recall the ethical views of Tadeusz Kotarbiński (1976:36$37,63-67)$. On the one hand, he strongly highlighted the ideal of a friendly guardian, a person sensitive to one's needs, particularly those of people under their care, offering their reliable support. On the other hand, as a proponent of practical realism, he interpreted care primarily as a defense against evil, in accordance with the medical principle of primum non nocere. In the case of protection from harm and suffering, I prevent negative states, but my merits seem negligible because they boil down to preventing evil from happening in the real world. When morality is understood as a duty to promote goodness, when I help, I bring about a certain good, we realize positive values-the source of merit. Therefore, when analyzing the duty to help, one should first determine whether it is more important to stop the expansion of evil than to promote good.

Should we, as caretakers, educators, parents, (SOCIETY), constantly protect children from the undisclosed "evil" of undefined colonialists, as well as constantly 
criticize the system? Or should we teach self-reliance and trust the subordinate subjects that they can create the good by becoming responsible for themselves, and show them that self-inflicted dependence and self-exclusion are tantamount to constantly running away from freedom? However, the choice is up to each of us.

An important question is whether contemporary education is post or rather neo-colonial. It is difficult to give a clear answer to this question. However, the above example (although briefly described) shows that the educational system is more neo-colonial rather than postcolonial. The consequence of such actions is exactly this neo-colonialism, which is based on the fact that the colonized people colonize themselves. The one who colonizes (the Ministry of National Education) offers people goods that are received with gratitude and willingness. To this end, the first art, which people need to train, is the art of giving. We need to learn to give in order to get as much as we can. The "final solution" of the "an-

\section{References}

Ashcroft, Bill. 1989. "Introduction." P. 1 in The Empire Writes Back: Theory and Practice in Post-Colonial Literatures, edited by B. Ashcroft, G. Griffiths, and H. Tiffin. London: Routledge.

Barnes, Colin. 2003. "Disability Studies: What's the Point?" Retrieved July 17, 2019 (https://disability-studies.leeds.ac.uk/ wp-content/uploads/sites/40/library/Barnes-Whats-thepoint.pdf).

Barnes, Colin and Geof Mercer. 2008. Niepetnosprawność [Disability]. Warsaw: Wydawnictwo Sic!

Barnes, Colin, Mike Oliver, and Len Barton, eds. 2002. Disability Studies Today. Bodmin: Polity Press.

Ben-Ari, Eyal. 1999. "Colonialism, Anthropology and the Politics of Professionalization. An Argumentative Afterword." Pp. 382- thropological question" is, therefore, brought about by giving, not extermination. It turns out that this is, in fact, the case, and as the additional value of the outlined discourse is the fact that we begin to understand the need to reflect on the condition of living with disabilities, being excluded, or subordinate in the context of neo-colonial pedagogy.

The peculiar entanglement in the appearance of pseudo-help and the attempt to show the mystification of the "traditional" pattern of discipline allows us to take a closer look at the social situation and locations occupied in the (public) space by people without disabilities and those with intellectual disabilities. "This prompts us to review the relations of subordination and dependence prevailing here, to reflect on the specificity of their (non-) symmetry, the placement of certain entities on the central or (with) marginalized/ peripheral positions, with a critical look at the succession of the existing knowledge and related practices and legacies" (Krzemińska 2019:325 [trans. MJ]).

409 in Anthropology and Colonialism in Asia nad Oceania, edited by J. van Bremen and A. Shimizu. Hong Kong: Psychology Press.

Berger, Peter L. 1988. Zaproszenie do socjologii [nvitation to Sociology]. Warsaw: Wydawnictwo PWN.

Bishop, Russell. 2009aupapa Māori. Przezwyciężyć noeokolonializm w badaniach społecznych [Freeing Ourselves from Neocolonial Domination in Research: A Kaupapa Māori Approach to Creating Knowledge]." Pp. 162-207 in Metody badań jakościowych [The Handbook of Qualitative Research], edited by N. K. Denzin and Y. S. Lincoln. Warsaw: Wydawnictwo Naukowe PWN.

Borowska-Beszta, Beata. 2016. “Wkład antropologii kulturowej w studia nad niepełnosprawnością [Contribution of Cultural Anthropology to the Study of Disability]." Interdyscyplinarne Konteksty Pedagogiki Specjalnej 15/2016:15-41. 
Canguilhem, Georges. 2000. Normalne i patologiczne [The Normal and the Pathological]. Gdansk: Wydawnictwo słowo/obraz terytoria.

Caulfield, Mina Davis. 1972. "Culture and Imperialism: Proposing a New Dialectic." Pp. 182-212 in Reinventing Anthropology, edited by D. Hymes. New York: Pantheon Books.

Chomsky, Noam. 2008. Interwencje [Interventions]. Katowice: Wydawnictwo Sonia Draga.

Chomsky, Noam. 2018. Siła i opinia [Force and Opinion]. Warsaw: Instytut Wydawniczy Książka i Prasa.

Crozier, Brian. 1964. Neo-Colonialism. A Background Book. London: Bodley Head.

Domańska, Ewa. 2008. "Badania postkolonialne [Postcolonial Research]." Pp. 157-165 in Teoria postkolonialna: wprowadzenie krytyczne [Postcolonial Theory: A Critical Introduction], edited by L. Gandhi. Poznan: Wydawnictwo Poznańskie.

Elzenberg, Henryk. 1994. Kłopot z istnieniem [Trouble with Existence]. Cracow: Wydawnictwo Znak.

Foucault, Michel. 1987. Historia szaleństwa w dobie klasycyzmu [History of Madness in the Classical Age]. Warsaw: Państwowy Instytut Wydawniczy.

Foucault, Michel. 2006. Stowa i rzeczy. Archeologia nauk humanistycznych [The Order of Things: An Archaeology of the Human Sciences]. Gdansk: Wydawnictwo słowo/obraz terytoria.

Frankfurt, Harry Gordon. 2005. On Bullshit. Princeton: Princeton University Press. Retrieved January 02, 2021 (http://www2.csudh. edu/ccauthen/576f12/frankfurt__harry_-_on_bullshit.pdf).

Gajdzica, Zenon. 2013. Człowiek z niepełnosprawnością w rezerwacie przestrzeni publicznej [A Man with a Disability in a Public Space Reserve]. Cracow: Oficyna Wydawnicza Impuls.

Gandhi, Leela, ed. 2008. Teoria postkolonialna: wprowadzenie krytyczne [Postcolonial Theory: A Critical Introduction]. Poznan: Wydawnictwo Poznańskie.

Goffman, Erving. 2011. Relacje w przestrzeni publicznej. Mikrostudia porzadku publicznego [Relations in Public. Microstudies of the Public Order]. Warsaw: Wydawnictwo Naukowe PWN.

Grążawski, Mariusz. 2011. "Wychowanie do demokracji przez działalność samorządu uczniowskiego [Education to Democracy through the Activity of Student Government]." Pp. 29-36 in Samorzadność wczoraj i dziś. Wychowanie do społeczeństwa obywatelskiego [Self-Management Yesterday and Today. Education for a Civil Society], edited by A. Murzyn. Cracow: Oficyna Wydawnicza Impuls.

Huntington, Samuel P. 2007. Zderzenie cywilizacji [The Clash of Civilizations]. Warsaw: Muza.

Jabłoński, Maciej. 2016. “Rezerwaty i przestrzenie włączające w przestrzeni rzeczywistości szkolnej [Reserves and Inclusive Spaces in the Area of School Reality]." Problemy Edukacji, Rehabilitacji i Socjalizacji Osób Niepetnosprawnych 22(1/2016):74-97.

Jabłoński, Maciej. 2018. Jakość życia mężczyzn z niepetnosprawnościa intelektualna. Badanie w działaniu [Quality of Life for Men with Intellectual Disabilities. Study in Action]. Bydgoszcz: Wydawnictwo Uniwersytetu Kazimierza Wielkiego.

Jacoby, Russell. 1995. "Marginal Returns: The Trouble with Post-Colonial Theory." Lingua Franca September/October:30-37.

Kamiński, Aleksander. 1965. Samorzad młodzieży jako metoda wychowawcza [Youth Government as an Educational Method]. Warsaw: Państwowe Zakłady Wydawnictw Szkolnych.

Kennedy, Dane. 2014. Dekolonizacja. Krótkie wprowadzenie [Decolonization. A Very Short Introduction]. Lodz: Wydawnictwo Uniwersytetu Łódzkiego.

Kosek-Nita, Bogumiła and Danuta Raś. 2000. Kontakty z ludźmi innymi jako problem opieki, wychowania $i$ resocjalizacji [Contacts with Different People as a Problem of Care, Education, and Rehabilitation]. Katowice: Wydawnictwo Uniwersytetu Śląskiego.

Kościelska, Małgorzata. 1995. Oblicza upośledzenia [Faces of Disability]. Warsaw: Wydawnictwo Naukowe PWN.

Kotarbiński, Tadeusz. 1976. Medytacje o życiu godziwym [Meditations on a Decent Life]. Warsaw: Wiedza Powszechna.

Kowalik, Stanisław. 2012. "Pomoc w dochodzeniu i utrzymaniu własnej dorosłości przez osoby niepełnosprawne [Assistance in Achieving and Maintaining Own Adulthood by Disabled People]." Pp. 35-46 in Niepetnośprawność w zwierciadle dorosłości [Disability in the Mirror of Adulthood], edited by R. Kijak. Cracow: Oficyna Wydawnicza Impuls.

Krzemińska, Dorota. 2012. Język i dyskurs codzienny osób z niepetnosprawnościa intelektualna [Language and Everyday Discourse of People with Intellectual Disabilities]. Cracow: Oficyna Wydawnicza Impuls. 
Krzemińska, Dorota. 2019. Być para z niepetnosprawnością intelektualna. Studium mikroetnograficzne w kontekście teorii postkolonialnej Homiego K. Bhabhy [To Be a Couple with an Intellectual Disability. A Microethnographic Study in the Context of Homi K. Bhabha's Postcolonial Theory]. Cracow: Oficyna Wydawnicza Impuls.

Loomba, Ania. 2005. Colonialism/Postcolonialism, 2nd ed. London, New York: Routledge.

Loomba, Ania. 2011. Kolonializm/postkolonializm [Colonialism/ Postcolonialism]. Poznan: Wydawnictwo Poznańskie.

Malendowski, Włodzimierz. 2000. “System kolonialny, dekolonizacja, neokolonializm [Colonial System, Decolonization, Neocolonialism]." Pp. 289-306 in Stosunki międzynarodowe [International Relations], edited by W. Malendowski and C. Mojsiewicz. Wroclaw: Atla 2.

Misiarz-Filipek, Sabina. 2015. "Przemoc symboliczna w powieści 'Szum' Magdaleny Tulli [Symbolic Violence in the Novel 'Szum' by Magdalena Tulli]." Pp. 10-18 in Powrót przemocy [The Return of Violence], edited by A. Stańczak et al. Lublin: Firma Handlowo-Usługowa „PANDORA” Anna Panek.

Ngũgĩwa, Thiong'o. 1986. Decolonising the Mind. The Politics of Language in African Literature. London: James Currey.

Nowak, Piotr. 2014. “Edytorial [Editorial].” Kronos 4:4-5.

Pels, Peter. 1997. "The Anthropology of Colonialism: Culture, History, and the Emergence of Western Governmentality." Annual Review of Anthropology 26:163-183.

Podgórska-Jachnik, Dorota. 2016. “Studia nad niepełnosprawnością (Disability Studies) i ruch włączający w społeczeństwie jako konteksty edukacji włączającej [Disability Studies and the Inclusive Movement in Society as Contexts of Inclusive Education]." Problemy Edukacji, Rehabilitacji i Socjalizacji Osób Niepetnosprawnych 22(1/2016):14-37.

Radziewicz, Julian. 1985. Równi wśród równych, czyli o samorzadzie uczniowskim [Equals among Equals-About the Student Government]. Warsaw: Instytut Wydawniczy Nasza Księgarnia.
Rzeźnicka-Krupa, Jolanta. 2009. Niepetnosprawność i świat spoteczny. Szkice metodologiczne [Disability and the Social World. Methodological Sketches]. Cracow: Oficyna Wydawnicza Impuls.

Seth, Sanjay, Leela Gandhi, and Michael Dutton. 1998. "Postcolonial Studies: A Beginning..." Postcolonial Studies 1(1):7-11.

Songin-Mokrzan, Marta. 2014. Zwrot ku zaangażowaniu. Strategie konstruowania nowej tożsamości antropologii [A Turn towards Involvement. Strategies for Constructing a New Identity of Anthropology]. Lodz, Wroclaw: Polskie Towarzystwo Ludoznawcze.

Śliwerski, Bogusław. 2011. “Niezdolność uspołecznienia polskiej oświaty w okresie dwudziestolecia III RP [Inability to Socialize Polish Education in the Twenty Years of the Third Polish Republic]." Pp. 9-27 in Samorzadność woczoraj i dziś. Wychowanie do społeczeństwa obywatelskiego [Self-Management Yesterday and Today. Education for a Civil Society], edited by A. Murzyn. Cracow: Oficyna Wydawnicza Impuls.

Wlazło, Marcin. 2014. “Prekariat i niepełnosprawność - o tymczasowości i niepewności edukacji, rehabilitacji, pracy i życia [The Precariat and Disability-About the Temporality and Uncertainty of Education, Rehabilitation, Work, and Life]." Interdyscyplinarne Konteksty Pedagogiki Specjalnej 6/2014:33-47.

Young, Robert J. C. 2012. Postkolonializm [Postcolonialism]. Cracow: Wydawnictwo Uniwersytetu Jagiellońskiego.

Zakrzewska-Manterys, Elżbieta. 2010. Upośledzeni umysłowo. Poza granicami człowieczeństwa [Mentally Handicapped. Beyond Humanity]. Warsaw: Wydawnictwo Uniwersytetu Warszawskiego.

Żółkowska, Teresa. 2010. “Od medyczno-przedmiotowych do humanistyczno-podmiotowych koncepcji niepełnosprawności [From Medico-Objective to Humanistic-Subjective Concepts of Disability]." In Uczeń o specjalnych potrzebach w przestrzeni wspótczesnego systemu edukacji [A Student with Special Needs in the Area of the Modern Education System], edited by Z. Janiszewska-Nieścioruk. Zielona Gora: Oficyna Wydawnicza UZ.

Žižek, Slavoj. 2010 Przemoc. Sześć spojrzeń z ukosa [Violence. Six Sideways Reflections]. Warsaw: Muza.

\section{Citation}

Jabłoński, Maciej. 2021. “The 'Illusion' of Social Research/Action. Reflections on Neo-Colonial Pedagogy.” Qualitative Sociology Review 17(1):96-109. Retrieved Month, Year (http://www.qualitativesociologyreview.org/ENG/archive_eng.php). DOI: http://dx. doi.org/10.18778/1733-8077.17.1.7 